\title{
PATIENCE IN MOSLEM EVANGELIZATION
}

\section{"Ye have need of patience" Heb. IO:36.}

At the very outset it is well to notice that the Biblical conception of Patience differs considerable from our modern use of the word. Influenced, perhaps, by centuries of monasticism, we are inclined to connect the thought of patience with that of a quiet passivism, slowness to anger, a patient forbearance. This thought, with a special Greek word, has its place in the New Testament, but it is a very small place compared to the word more generally translated "patience." Patience in the New Testament is a word full of virility. It is the patient endurance of the soldier that gives him the fruits of victory, just as it is almost beyond his grasp, by what has been so aptly called "stick-at-it-ness."

Amongst a very large number of historical examples, perhaps the war has furnished the most startling illustration of irreparable loss through lack of this virtue. When the Germans in their first great drive towards Paris had broken down one line of resistance after another, at one vital part of the line there remained, if they had only known it, a thin, weak, extemporized line of non-combatant units, and it was at this psychological moment that they failed to continue their push at this particular sector; that their patience, in the New Testament meaning of the word, failed.

There can be no doubt that this virtue is the great need not only of missionaries to Mohammedans and their Home Boards, but of those that support them in prayer and with their substance. Compared with other mission fields, there is little encouragement from the visible results of the work. It is essentially a work of faith, though we must not forget that faith reacts on sight, opening the eyes to see and understand God's wonderful workings amongst Mohammedans, and His prepara- 
tion of them for the reception of our glorious message.

For all who seek the evangelization of the Moslem World, there comes the message "Ye have need of $\mathrm{Pa}$ tience," patient, virile, courageous endurance, coupled with diligent faith and free from sluggishness, fainthearted flinching and drawing back. A most valuable study with this end in view can be made of the Epistle to the Hebrews, taking Patience as the keyword. I do not propose here to enter at all fully into the teaching of the book along these lines, or to refer to its wellknown primary application, but only to give a hint as to its value to us, hoping that those who read this article will turn to the Epistle and prayerfully study it for themselves.

First let us look at some of the marks of those who had drawn back, of those who had gone far and then fell away, and who were to be a warning to those who were in danger of doing so.

(1). They had been so long under instruction that they ought to have been teachers, yet they had become children in intelligence.

(2). They had been slothful, sluggish, slack about inheriting the promises, not steadfastly believing them and making them theirs.

(3). They had been neglecting true Christian fellowship and so failed to provoke one another to love and good works.

(4). They had neglected the word of God, "spoken to us in a Son," and had been consequently carried away with divers and strange doctrines. (This is the great ever-recurring warning, running through the whole Epistle.)

(5). They had cast away their joyful confidence with its great recompense of reward.

Let us now seek to apply some of these warnings. It is not an easy matter to become an intelligent teacher of Mohammedans, understanding their mentality and applying the great truths of the Gospel to them in an effective way. Time should be ever bridging the mental gulf between the Mohammedan and the would-be 
Christian teacher. Are there not many who having started with confident assurance that they were called of God to this work, have not grown more effective in their power of presenting the Gospel to Mohammedans. They seem to have become satisfied with the routinework of a missionary's life, becoming less and less effective as the years have gone by. This is not only a loss to the Mohammedans to whom God intended them to be the messengers, but is fraught with spiritual danger to themselves.

The Word of God is full of promises for the worker among Mohammedans, and has some especially bright promises for particular fields. Are missionaries laying hold of these promises, making them theirs, and receiv. ing from them a full assurance of hope. Or are they allowing so called modern scholarship to present them with a Bible that is emasculated of the revealed truth of God that is intended to be "a light that shineth in a dark place, until the day dawns?" Then there are other promises, of spiritual endowment, without which all the mental bridging of the gulf between Mohammedan and teacher will be of no avail. Are we being diligent in laying hold of these? And again there is the spirit of wisdom and revelation that enables us to look right past the present and to get a vision of the hope of our calling, to get a vista of the wonderful purposes of God in gathering to Himself a people of all nations, and kindreds, and people, and tongues.

Do we at all realize the importance of Christian fellowship, a real Christian fellowship, not a mere perfunctory coming together of Christians, but a meeting together with purpose of heart to meet together with God? "I thank Thee, O Lord, that Thou hast placed so many lights in the upper chamber-so many and so varied. I thank Thee that I do not need to take my rule from one, that each can see his own star in Thy sky. And yet I thank Thee still more that I do not need to rest in my own star. Thou hast ordained many lights, not only to prepare a place for me, but to prepare for me many places. Thou wouldst have me, not merely 
to keep my own glow, but to get from others the color which in me is dim. Thou hast put Peter beside John that the impulsiveness of Peter may be moderated; Thou hast put John beside Peter that the slowness of John may be quickened. Illuminate me by my brother's light. Give to my love the quality in which it is not strong. Let me catch the impress of the opposite star. Let me press toward the gate by which $I$ have not found Thee, but by which my brother has found Thee. Help me to sympathize with those who have entered by another door of Thy temple. Reveal to me that my song of praise is not complete till it blends with a counterpart in the great symphony. I shall know the meaning of the many voices when I learn the need of Thy manifold grace." So prayed Dr. George Matheson, the author of "O Love that will not let me go."

Surely it is unnecessary for us here to emphasize the supreme importance of a continuous devotional reading of God's Word that we may learn to know Him who is the Living Word of God, the Son in whom $\mathrm{He}$ has spoken to us. If through the pressure of work we neglect this, how soon will we lose the buoyant confidence of a sure and stedfast hope. Yes, surely we have need of steady patience, so that after doing the will of God we may get what we have been promised.

Whilst in many Mohammedan lands of the near East work amongst Mohammedans has been stopped by the War and in others has had to be greatly modified, God has been working as only $\mathrm{He}$ can work, but in His wisdom there is some of the work that will not be done unless we do it. Will $\mathrm{He}$ find us patiently enduring, ready and keen for the next offensive, all alert to "go over the top," or will He find some who have drawn back, some whose hands are hanging down, whose knees are feeble?

These words have been mostly directed to the missionary, but just as we have learned in these days that the Army on the field, the Army in preparation, the Army of organizers and the Army of munition workers are 
all one, and that without the best efforts of the others the Army on the field is crippled, so we all at home and on the field need this great fighting quality of patience, of steady endurance, that we may win through. The limits, however, of a magazine article constrain me to leave to the reader these applications to the home end.

Suffer a final word with regard to what $I$ have termed above the Army of Preparation. From one cause and another during these years of war, reinforcements have not been coming to the field. Some who were ready to come have drawn back on account of the long wait caused by restrictions on travel. Every missionary so. ciety working amongst Mohammedans is on this account faced with a grave crisis. Ranks need filling up. Front line troops need relief. Reinforcements need rapid and specialized training. These are matters that call for urgent prayer and faith. The present is no time for drawing back, no time even for letting organizations that have been started in the past to "carry on" with what is left them their initial momentum. "Ye have need of patience," the patience of a racer that has his eye on the goal and who makes his supreme effort towards the end of the race. "Forgetting the things that are behind, pressing forward towards the mark." "So run that ye may obtain."

Grorge SwaN. 